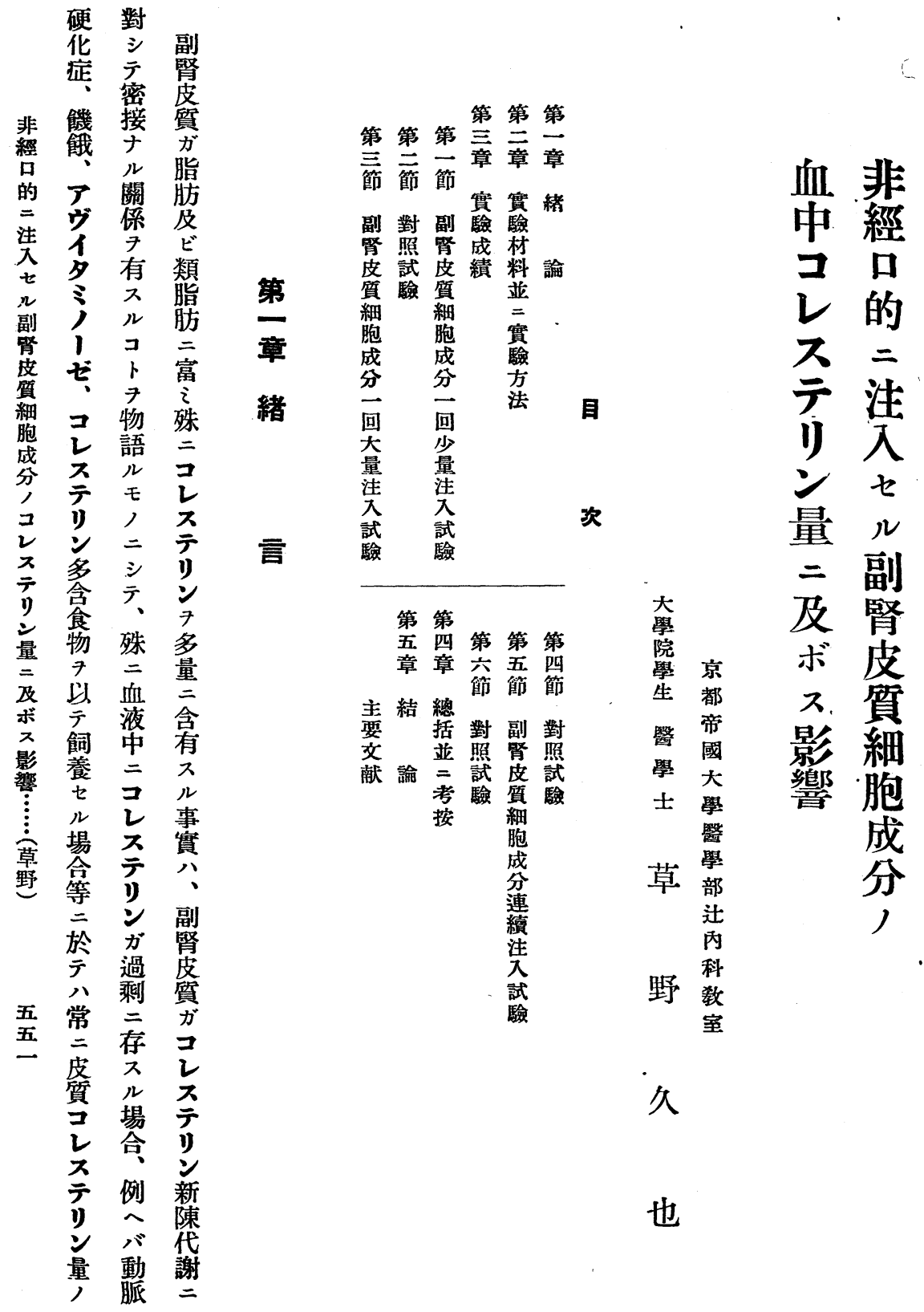




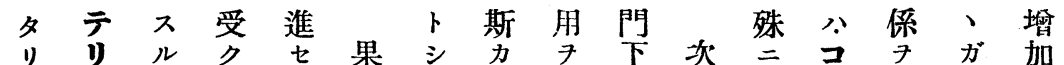
ソモル 量・ナメテ库特ボヨ臟レスス, 來 其ル 或然生異 シ ル器 $テ テ ゙$ 際ス 非 變ノべハラシ ナ、多細エリコニコ 經 動多キ減バタル適數胞ス ン ン ト

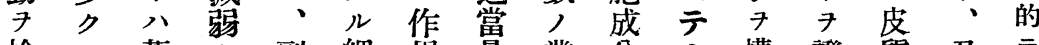

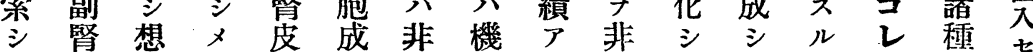

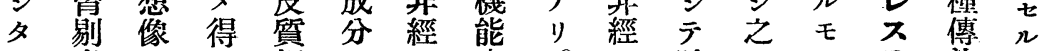

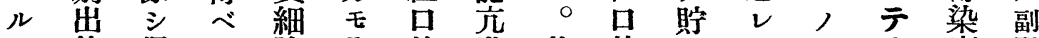
モ後得ク胞全的進其的人

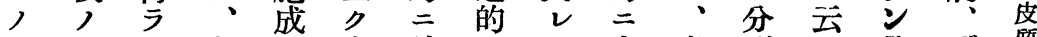
ナ血ル 其分之外二二生必泌

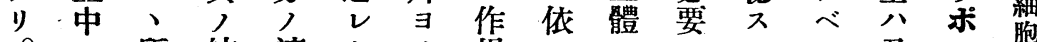
依レ゙所結 適

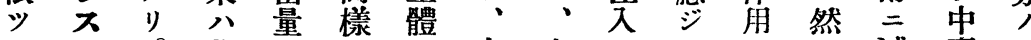

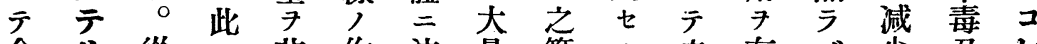
余り 從 之量副密經用入 之量腎挼的有

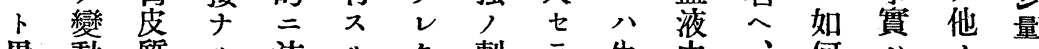
異動質 ル 注ルタ刺ラ生中、何八,

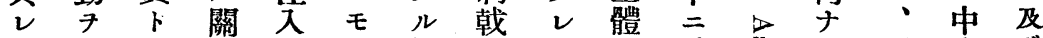

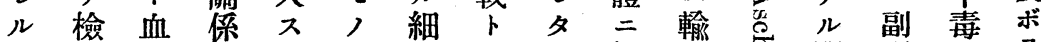

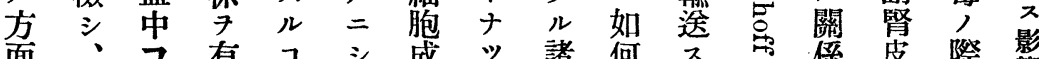
面、コ有コシ成 $ッ$ 諸何 ス品係皮際影 ヨ或レストテ分テ臟ナル等二質二 リ 两副デル ニ

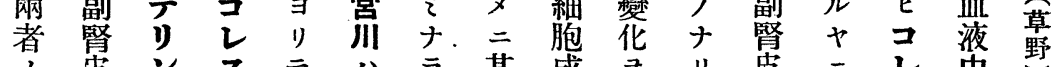
菠

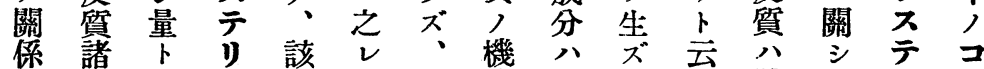
種, ン 動 體能該ル 方體デリレ

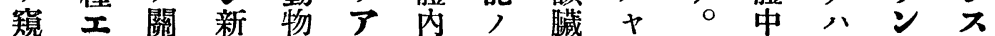
知キ係陳, ウ二減器二, 新テ五

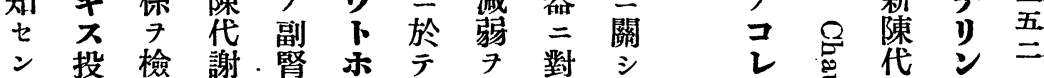
卜興索公皮儿新來シ 欲二七質モ陳ス テ ショル 何, ン代上顯 本儿業等 機卜謝云著宮

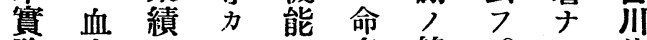
噞中八, 7 名終 0 儿並 7 多影或七术而刺二 企乙數響分り宸 シ 韩 其 テ 存 7 艺。物テ作了

ᄂ 代 $y=$

ス勱謝

テ 多

》2哈量 等 フ 八密消 貯皮接 費 藏質ナセ シ細關 ル 


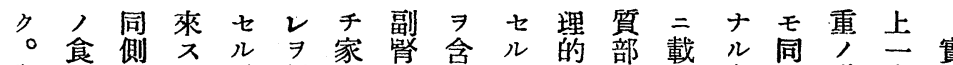

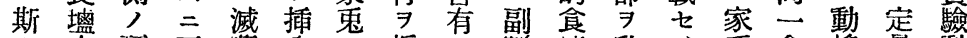

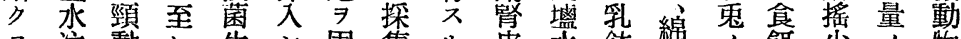

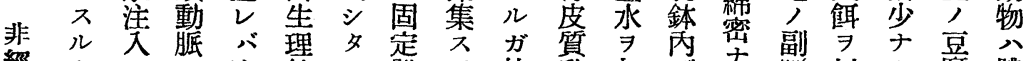

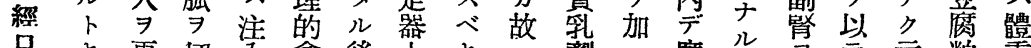

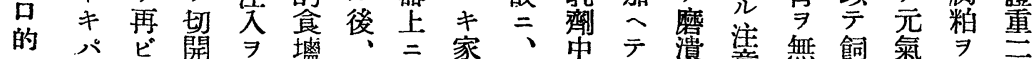

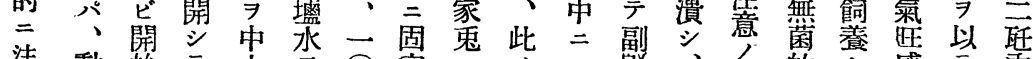
注動 始テ步㳊

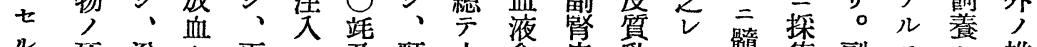

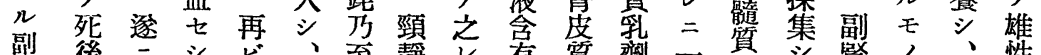

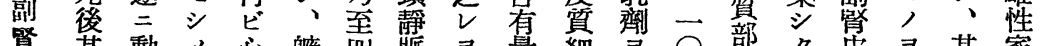
留其動 $x$ 心稚四胍 7 量細 $7 \bigcirc$

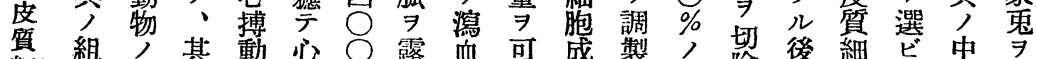

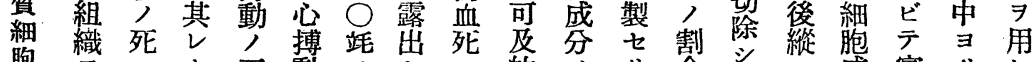
胞 $\Rightarrow=卜$ 正動 $>$ 三 的, リ合 威檢至同調分攝 テ致少外。卟斯切分驗食、 分ス時卜不氐之等少斯ナ只斷卜三思購

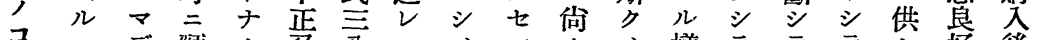

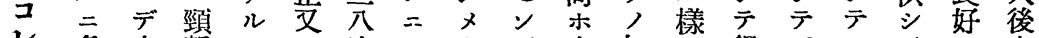

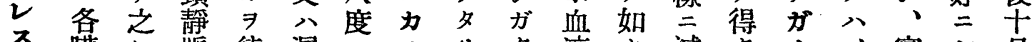

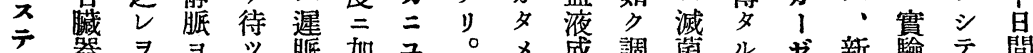

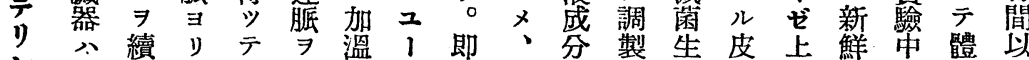
量

及及レトシ分》後站回站前八リリレ 采 ビ ス思。除二隔宛三宛記更。家斯作等

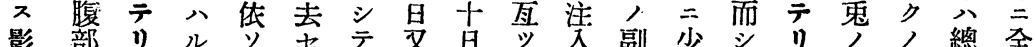
影部り 臓ン、

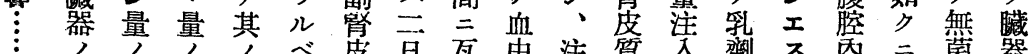

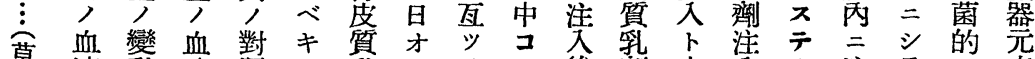

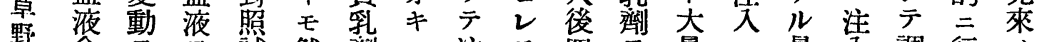

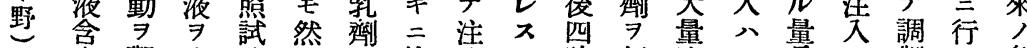

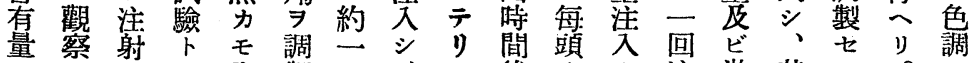

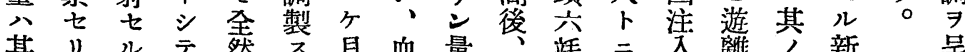

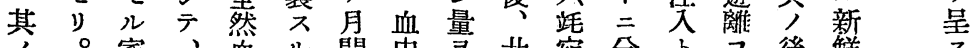
五 贜家大血 $九$ 間中夜 五器兔三凡

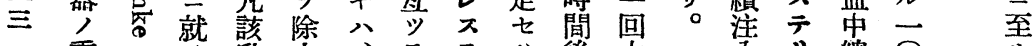

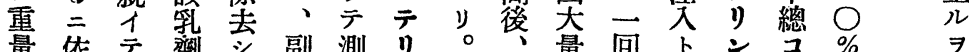

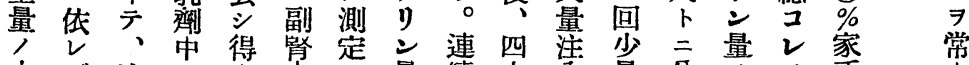

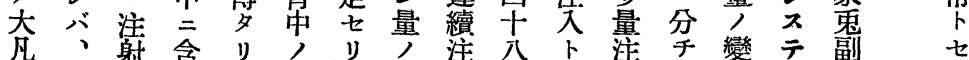

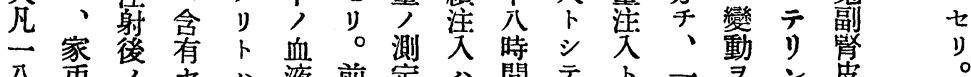

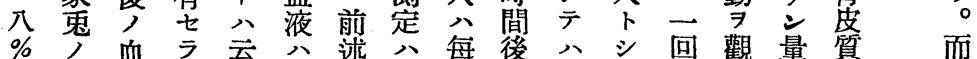

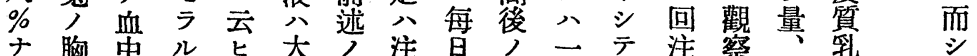

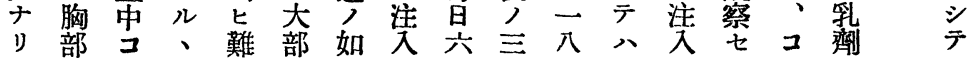



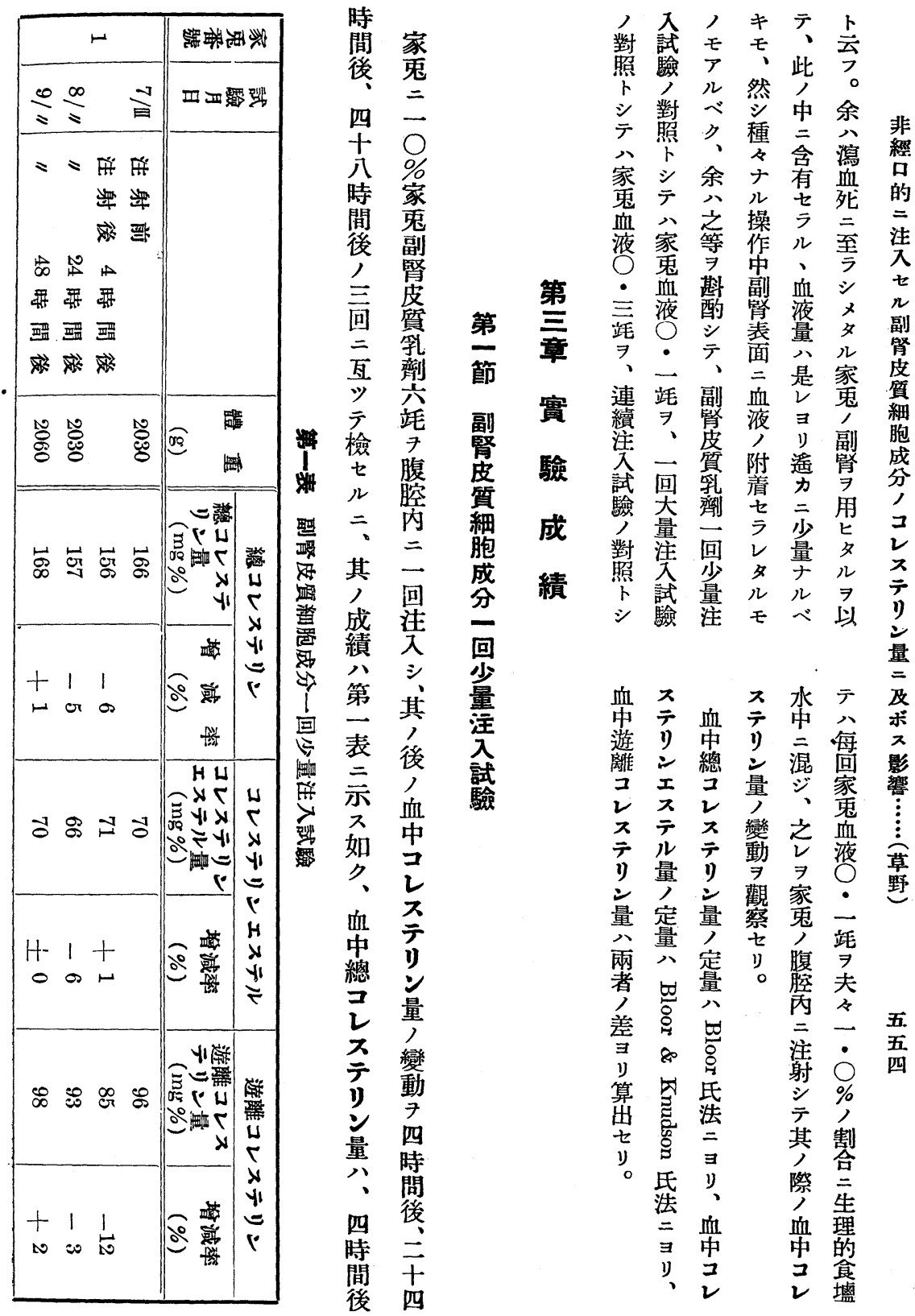


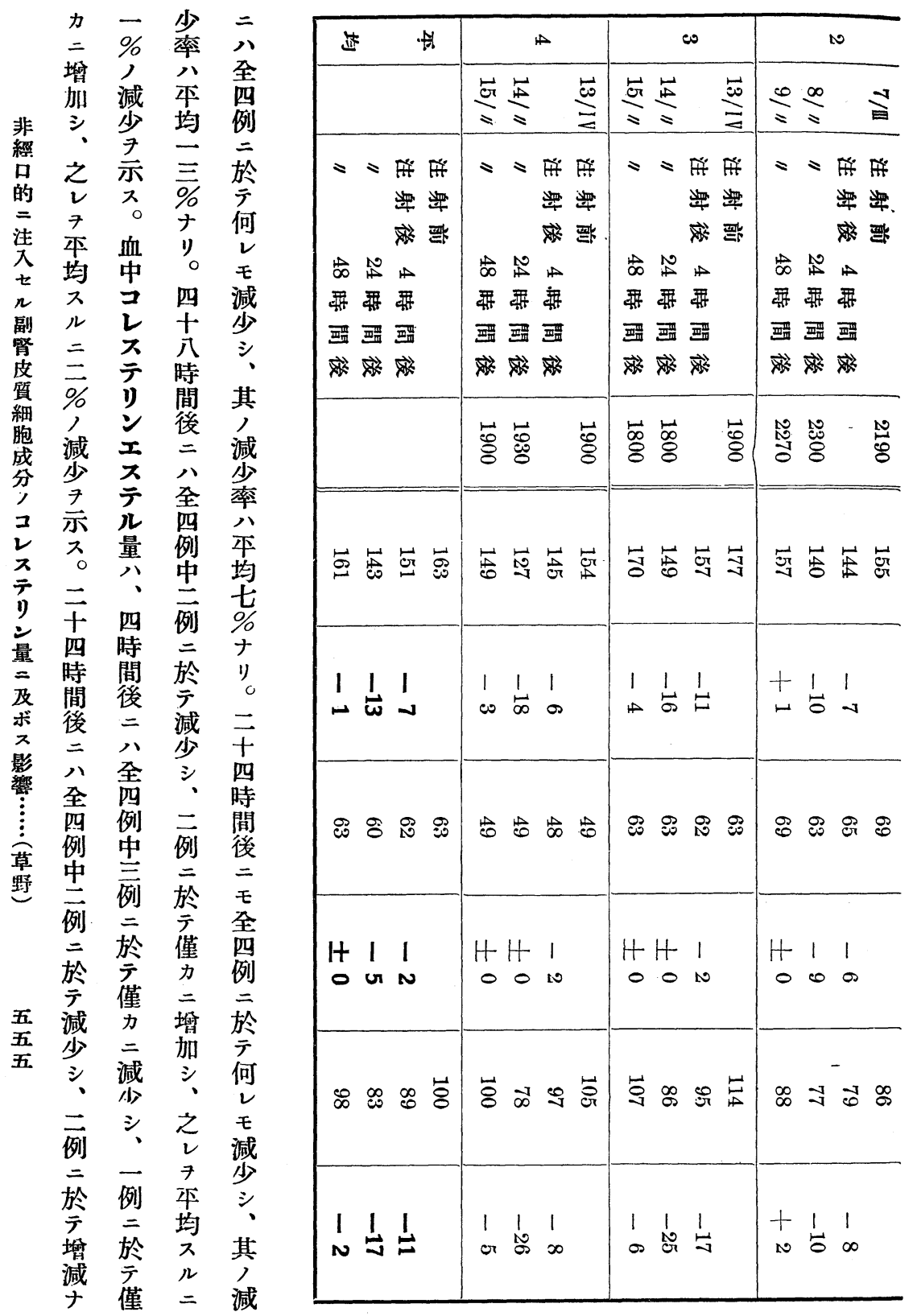




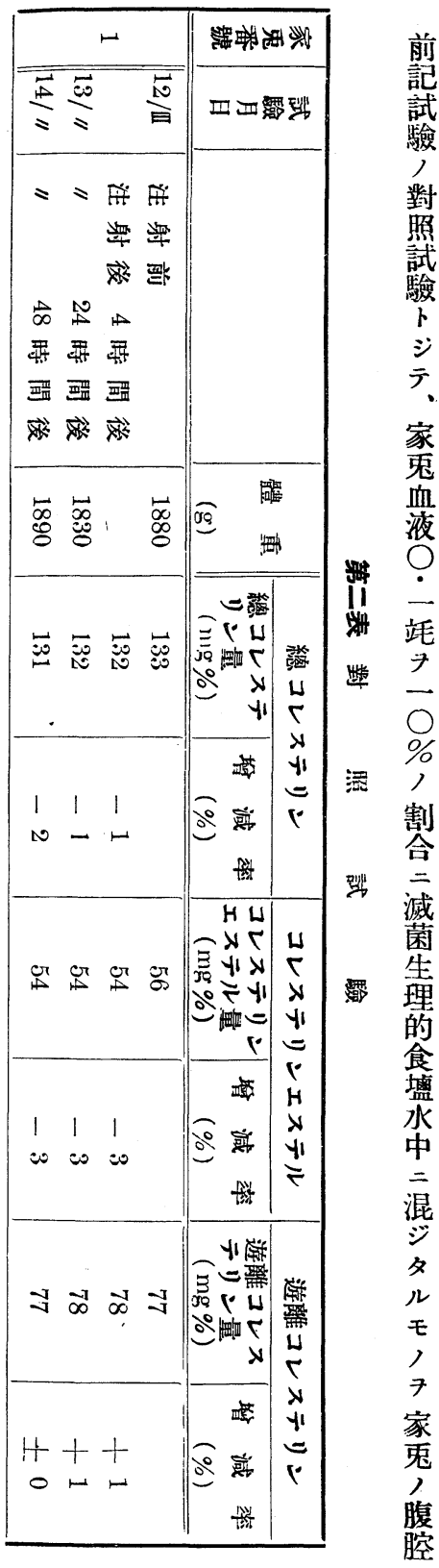

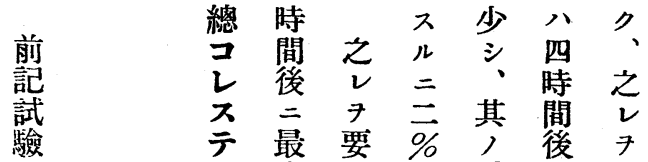

リ高要 \% 減後 本縔

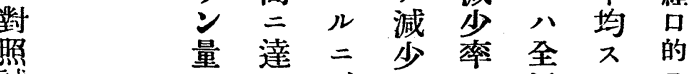

試当、少小四ル

驗減监示本例二注

卜 少後中均二五九

シ 二 漸 總 0 - 於 $\%$ 七

テ、第 伴 次 コ副

家 節 $\%$ 何減腎

鬼減値 テ

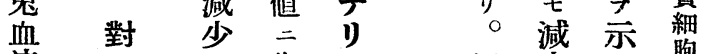

夜

照ル歸量十主。分

帚公 八四分,

試、時其十

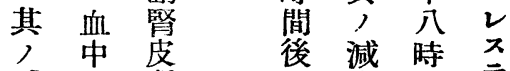

驗 当中皮後減㨍

減コ質 二 少閶 す

少乙細 八率後光

萃遊 否成 金本少量

離り分例均全及

コ 2 中 一四

ス ス 回省例 $\overrightarrow{\%}$ 例

テテ量 二ナ於 響

リ儿注於り量

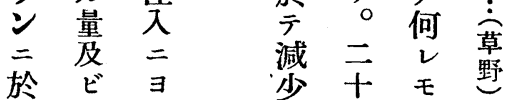

テ遊り シ 四增

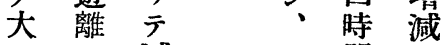

中 ナ当減 二間

混

棌

リレ 少

不

リ 減

少

量 率

例 後 シ

二 二 0 五.

於 モ 血 五

父注

何 入

檑 西 游

モ

7

家

腹

膑

後

血 $\overrightarrow{\text { t }}$

中 四

加例 離

シ 於

之 テ ス

何 $\bar{~}$

$\exists$ V

本モン

均減量 
テ例 八間 減二内

何中全後少: 二

ᄂ 示 三 率 其

非僅 $=$ 中全本成注

經力 於百均績 射

的減 僅 例 例

洼少妿於於 基

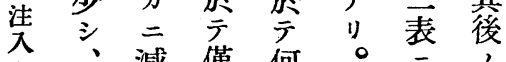

七 其少減僅 何 2 三示血

副

腎減、減僅四如 コ

皮少一少力時》レ

啠率例 シ 二間、、

胞八二、減後血 テ

成本於 至二中少二

分均留例 三八總

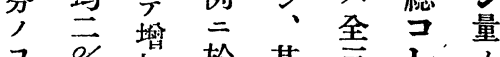

コ $\%$ 加 於 其 例 こ

スリシ、潎減 例 ス 變

门人減少於り整

血之年率 $\bar{ン}$ 四

量中

二遊尔、乎乞間

及離午之均毛、後

音至

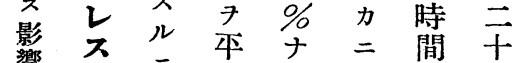

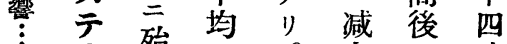

$\vdots$ ○殆 ス。少二洔

草 ン 增 $ル$ 血 シ 八間

野量城殆 中 其全後

、ナ名コ其豆四

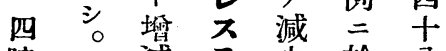

時減 テ少於八

間四ナり率 $テ$ 時

五後十

五二八。本公後

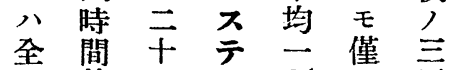

後四儿\%向

例二時 量ナ二二

中心間公》減互

全後四。少

例至二時四 三 స

二例 八間十檢 於文全後公其於

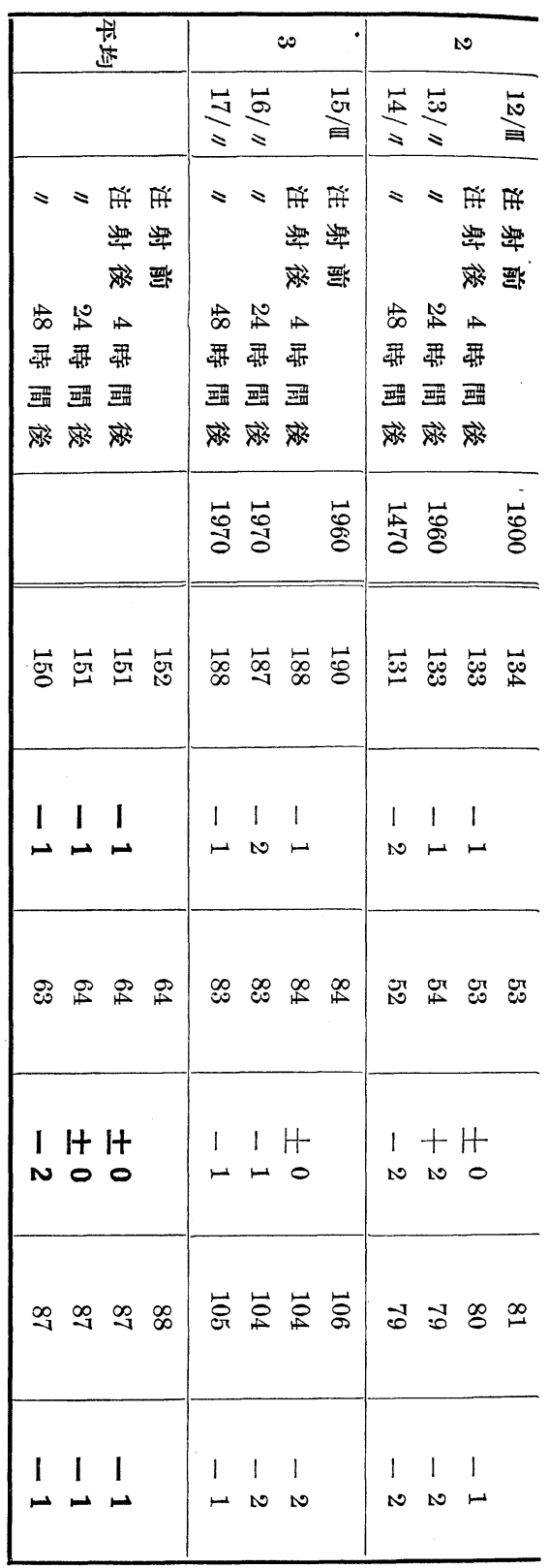




\begin{tabular}{|c|c|c|c|}
\hline$\leftarrow$ & & \multirow{2}{*}{\multicolumn{2}{|c|}{ 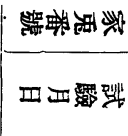 }} \\
\hline$\stackrel{\infty}{=} \cong$ & $\stackrel{-1}{\triangleq}$ & & \\
\hline 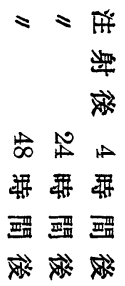 & 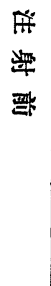 & & \\
\hline 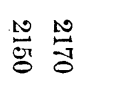 & $\stackrel{N}{\stackrel{N}{00}}$ & 宏 & 根 \\
\hline 鳬 $\vec{\jmath}$ & $\overrightarrow{e r g}$ & 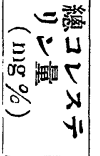 & 瓷 \\
\hline $\begin{array}{l}+ \pm+ \\
-\underset{\perp}{ \pm} \infty\end{array}$ & & 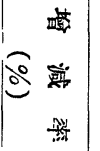 & $\underbrace{41}_{0}$ \\
\hline$\infty \ddot{\nexists}$ & $\stackrel{\infty}{\infty}$ & 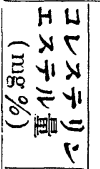 & $\begin{array}{l}u \\
r \\
x \\
y \\
y\end{array}$ \\
\hline $\begin{array}{l}H+H \\
0 \neq 0\end{array}$ & & 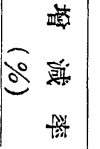 & $\begin{array}{l}H \\
H \\
y_{1} \\
y_{1} \\
F\end{array}$ \\
\hline$\infty \ddot{\circ} \&$ & $\stackrel{\infty}{-\infty}$ & 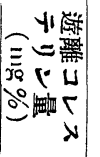 & 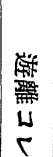 \\
\hline$+\frac{1}{N}+$ & & 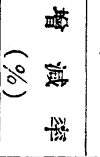 & $\begin{array}{l}x \\
41 \\
= \\
0\end{array}$ \\
\hline
\end{tabular}

後四

二時 家

八間 兔

全 後 二

例四

於入 $\%$

テ 時 兔

何間 副

後腎

モ, 皮

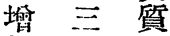

加回孚

シ 二 劑

其互

其 兴 公

iil

III 增 檢

加七腹

率儿腔

䁏 公二 內

本、二

其 一

九, 回

ナ 威 进

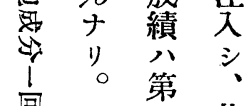

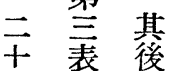

四 三 ?

時示 血

間不中

後如

モ ク、ス

全 血 テ

四中》

例 總 ン

二 コ 量

於光

テ ス 變

何 テ

モン四

筧 量 時

加 間

シ、四後

其蒔 間 $\begin{array}{lll}\text { 示之 } & \text { 於 } & \text { 僅 } \\ \text { サ } & \text { 僅 } & \\ \text { カ } & \end{array}$

ズ カ 二減

要 二 隇少 非

ス 減 少 縔

ル 少シ、 一 品

二、—例 =

血 - 例 二 注

中例二於 七

總二於 テ艺

第

於 亏 僅 副

レテ僅力腎

万鈤力二皮

テ減二增 質

副りナ塯加細

ソ 加 シ 胞

量、方、嵗

= 之 之

ᄂ 7 年

ス本 平 ス

テ均本均 テ

》入均不

ンルスル量

$I=ル=\stackrel{\text { 量 }}{=}$

ス 一 = 一 及

テ $\%$ - $\%$ ボ

几 $7 \%$ 万

量示, 減影

及

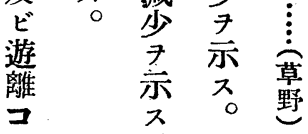

늠

テ + 四

リ八時

บ時 間 五

量 閏 後 五

何二小

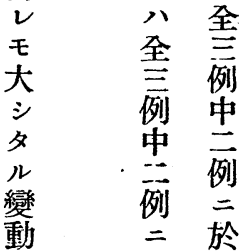




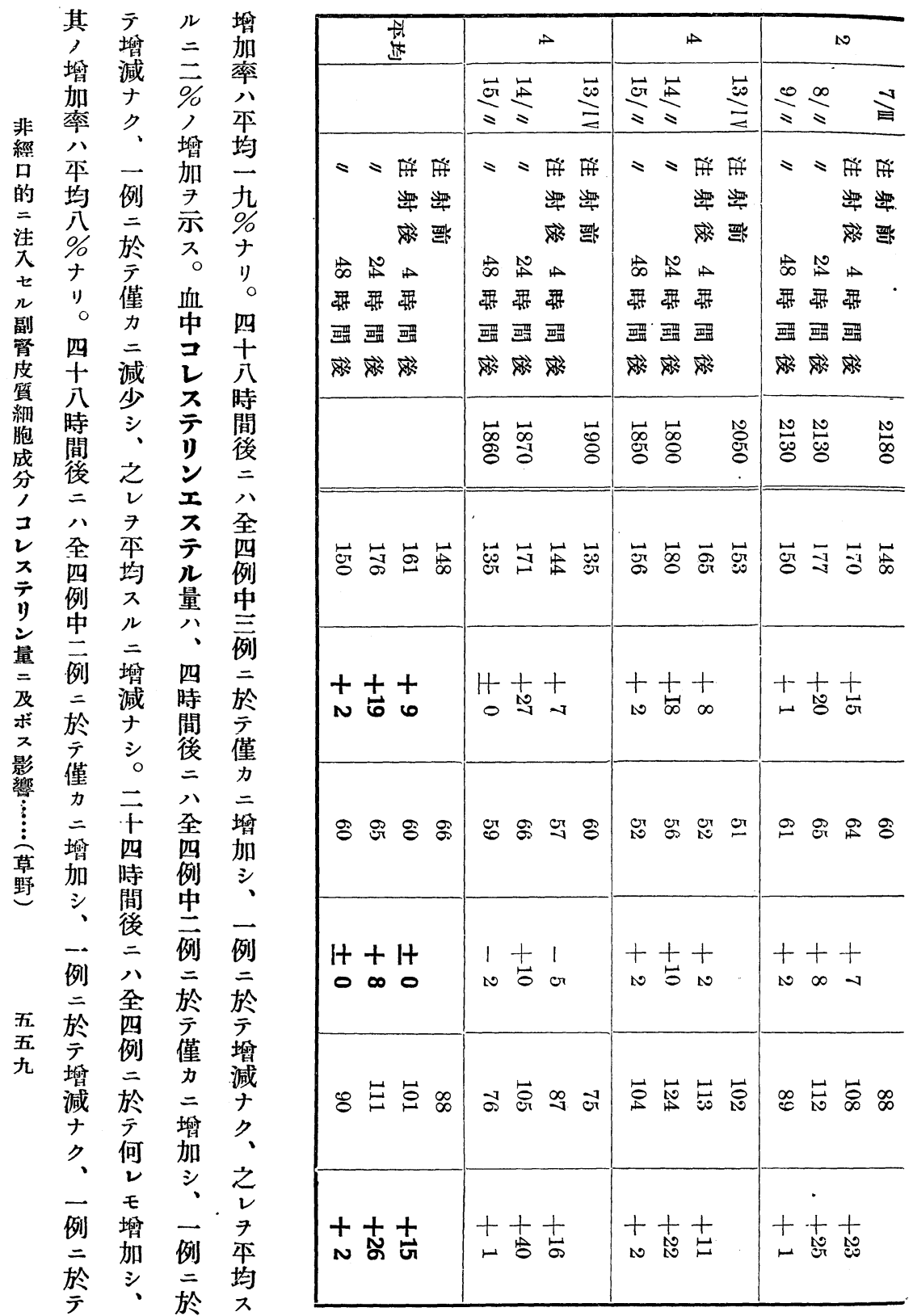




\begin{tabular}{|c|c|c|}
\hline - & \multicolumn{2}{|c|}{ 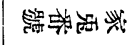 } \\
\hline 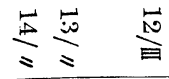 & 口四簿 & \\
\hline 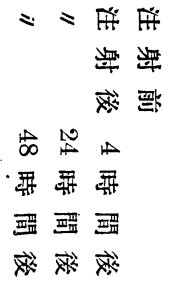 & & \\
\hline 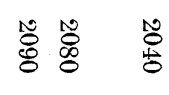 & 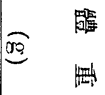 & \\
\hline $\overrightarrow{0}$ & 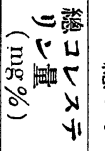 & 㗄 \\
\hline $\begin{array}{c}\cdot \\
1+1 \\
-\infty\end{array}$ & 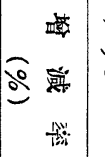 & $\underbrace{+1}_{0}$ \\
\hline gr $r \stackrel{r}{\sigma}$ & 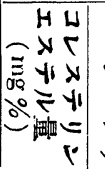 & $\begin{array}{l}w \\
r \\
v \\
y \\
=\end{array}$ \\
\hline $\begin{array}{l}1 H H \\
N 00\end{array}$ & ف0 & $\begin{array}{l}H \\
y \\
y 1 \\
F\end{array}$ \\
\hline$\stackrel{\infty}{\infty} \stackrel{\infty}{\circ} \stackrel{\infty}{\circ}$ & 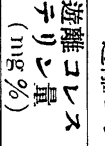 & 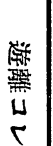 \\
\hline $\begin{array}{l}H+i \\
o-r\end{array}$ & 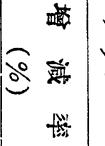 & $\begin{array}{l}x_{1} \\
= \\
0\end{array}$ \\
\hline
\end{tabular}

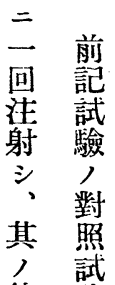

後羷

)

血 シ

中 テ

己 家

ス 兔

テ 血

$\checkmark 0$

量量

鍺變竓

紫動 尹

四

照

時 \%

間

後割

骂二

十 隇

四菌

時間

後的

四食

十些

八二

時 混

間 棌

兰 ル

$=$,

互 家

テ兔

檢

七腹

ル 檫
總 洔 後 檑 僅

コ間 之二加力

レ後レモ率二

ス二キ全八減

テ最要四本少非

リ高 ス 例均 シ 經

ン

量達二於五之 的

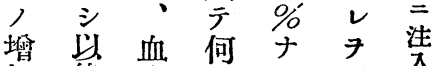

加後中河市入

二漸總 $乇 。$ 均 $九$

第件次 僅三

四光乞年干ル㹂

節厅人 万二四二皮

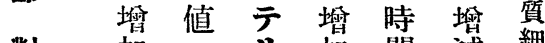

對加二 $=$ 加間減 細

ス復 ソ シ 後ナ荿

照䄪帚量、 二 シ 分

試无其モ

其血孯增西離

驗了中皮妿例寻

堆コ算率六 レ テ

茄 こ 細 交於

遊 テ 成均何 》

離り分三人方及

$\exists ン-\%$ 量

レエ回ナ壖少ス

ス ス大り加、影

テテ量○泪響

リル注、時

量 入 其間

二及二, 後草

於 ビ ヨ 習 二 野

テ遊り 加

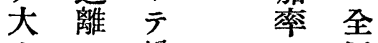

ナ口壖 八四

リ乙加本例

万均二五

テ

加 \% 何

量 率 ナ レ

八刀リを

、注。增

何 入四加

モ後主公

血十時其

中四間, 
少》、於僅力广其

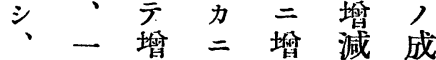

其 例減墦加 簀

非

纆減於 ク シ : 、第

口少亏、云之之四

的率僅 们之放

洼分力例 277

淮本二三 平平示

七均減於平均均不

几 学少示均入如

副 $\%$ 僅 スルルク

堅ナ、唹ル二二・

皮り之二二"

层。減一 \% \% 中

細血 7 少 $\%$, 總

胸出平三, 減減沓

感遊均: 減少少

分離 $九$ 少 77

ココル

ᄂ $2=7$ 示 $ᄌ$ ス

ス ス 平不。

テ テ $\frac{\pi}{\%}$ 均

り, 水血十十六

量ン減ル中八四

$=$ 量 少 $=$ ב時 時四

及公 7 增 乙 間 間時

沙、示減 ス 後後間

ス四スナテ二=後

影時。”分

管 間 四 ○ 全三八

後十二王㤗例全

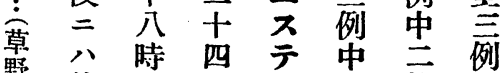

野前間時儿永例 中

例简量 例 立

中八 $=$ 、於示

五例前八四前僅於

六 例 金全間 僅

於二例後二減堡

云於 中 $=$ 減少

僅 亏 八少 シ 減

力 何例全 三 少

減壬於例

少僅 $\overline{\text { 中 例 }=-~}$

沙增三二於例

、減例於云云

\begin{tabular}{|c|c|c|}
\hline $\begin{array}{l}\text { 蓝 } \\
\end{array}$ & co & No \\
\hline & 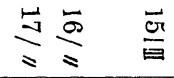 & $\stackrel{E}{\equiv}$ 点 \\
\hline 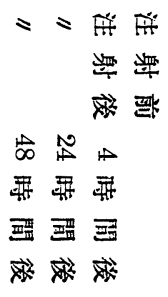 & 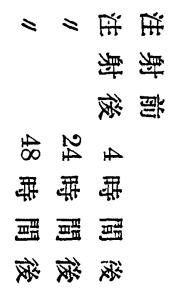 & 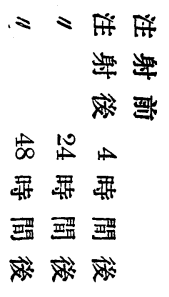 \\
\hline & 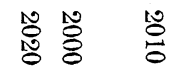 & 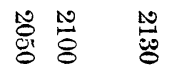 \\
\hline 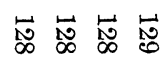 & 怘芯䓃䓃 & 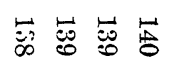 \\
\hline $\begin{array}{lll}1 . & 1 & 1 \\
- & - & -\end{array}$ & $\begin{array}{lll}+ & 1 & H \\
-10 & 0\end{array}$ & $\begin{array}{ccc}1 & 1 & 1 \\
-1 & -1 & -1\end{array}$ \\
\hline 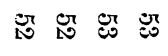 & Ir 80 o & gr gr gr \\
\hline $\begin{array}{lll}I & 1 & 1+ \\
N & N & 0\end{array}$ & $\begin{array}{lcc}1 & 1 & 1 \\
N & \infty & 1\end{array}$ & $\begin{array}{lll}1 & H & H \\
0 & 0 & 0\end{array}$ \\
\hline 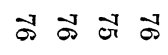 & 앙 용 욤 & 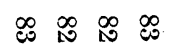 \\
\hline $\begin{array}{c}1+1+1 \\
00\end{array}$ & $\begin{array}{l}+\mathrm{H} \\
\text { co }\end{array}$ & $\begin{array}{lll}H & 1 & 1 \\
0 & -1\end{array}$ \\
\hline
\end{tabular}




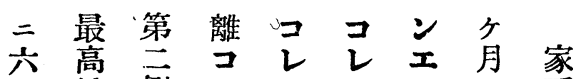

三 塯 例 ᄂ

$\%$ 加 元 テ テ テ 互 三

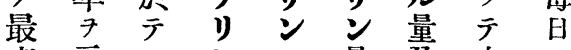

高示八ン工量庋血—

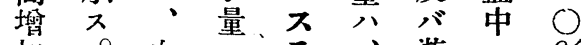

加 $○$ 血 心テテ、遊コ\%

率血中、儿注離し家

7 中 總六量入元兔

示ココ日開レテ 副

スレレ目、始スリ腎

○ス ス 二六後テン皮

血テテ三日亲り 量質

中リリ四目日时孚

遊: $ン \%$ 目 量 測 劑

離工量, 二公定兵

コス 聚七三何七竓

レテ、亭\%五レル宛

スル 注減, \% モ二

テ量入少最, 初、十

リ 開率高最 其日

ン、始 7 減高八了間

量六後示少減減成二

公亲 $三$ 率少少績 瓦

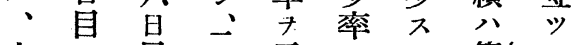

六二自市示年第

日 二 三

目 $\bigcirc$ 云百、後表腔

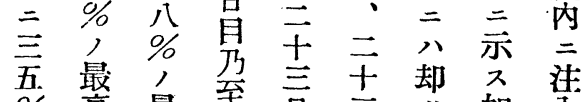

$\%$ 高最至亘三 $三$ 如入

最少減亭自自增 、

高率 少九二自加血注

減 7 卒音四入中、入

少示 7 目 $\%$ - 總 開

率 示六, $\%$ 即 コ 始

子、シ 六最人伡

示二、 $\overrightarrow{0}$ 高最第 ス 隔

シ十二\% 霄 高 一 テ 日

、旦十最加粭例り 又

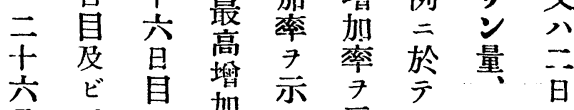

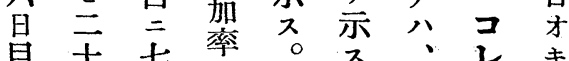

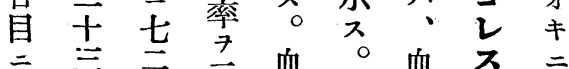

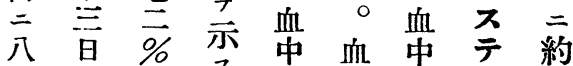

二目 $\%$ 示遊 中 總 リ

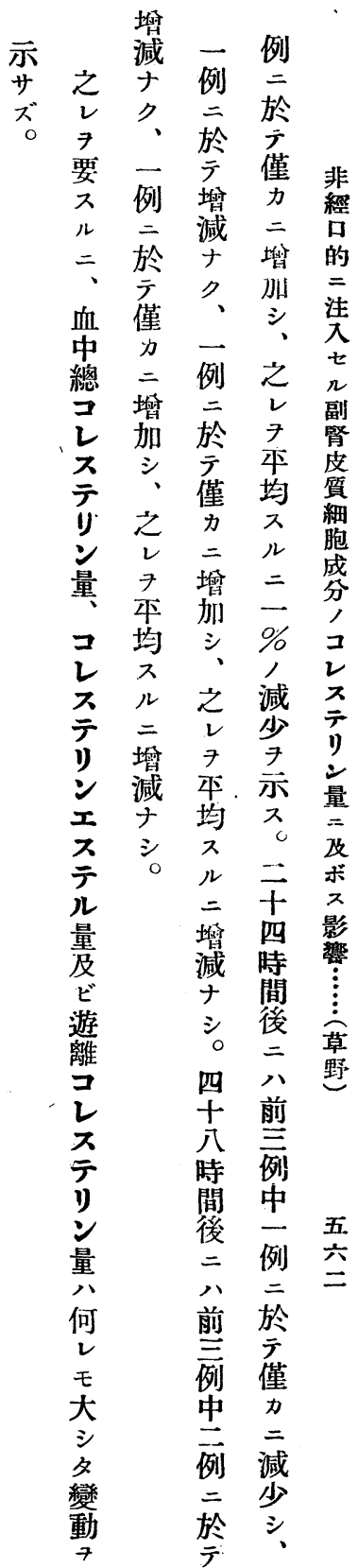




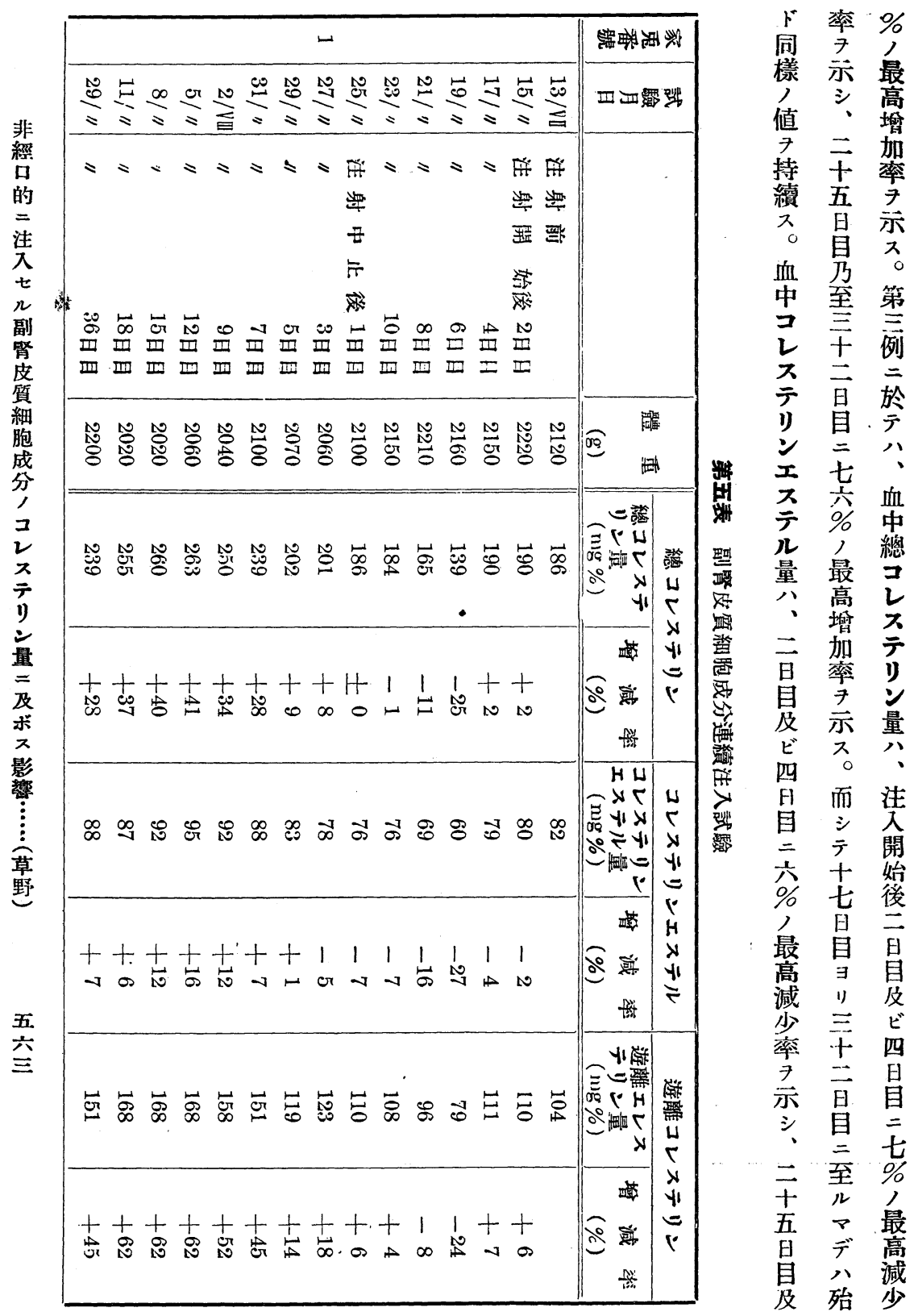




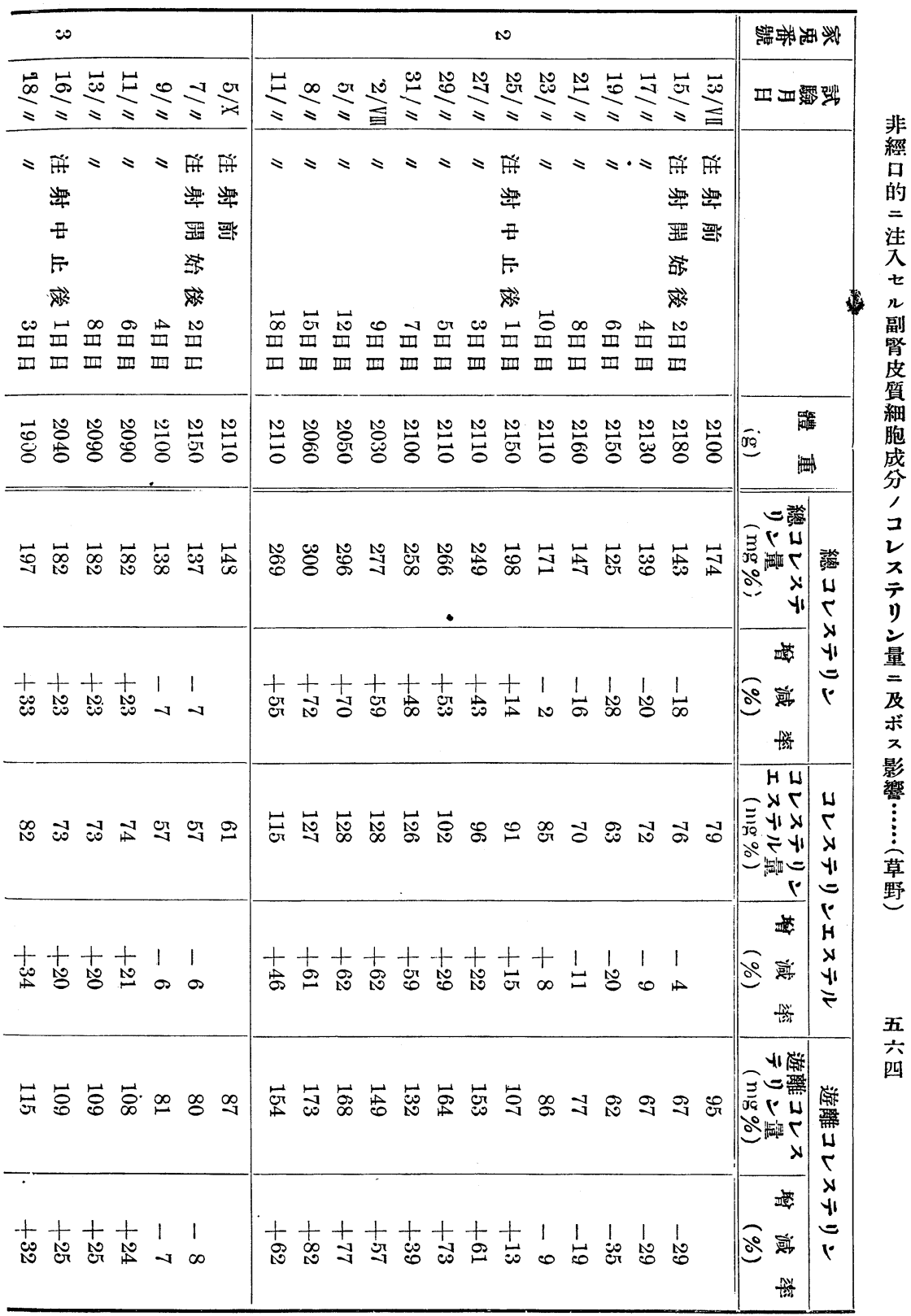




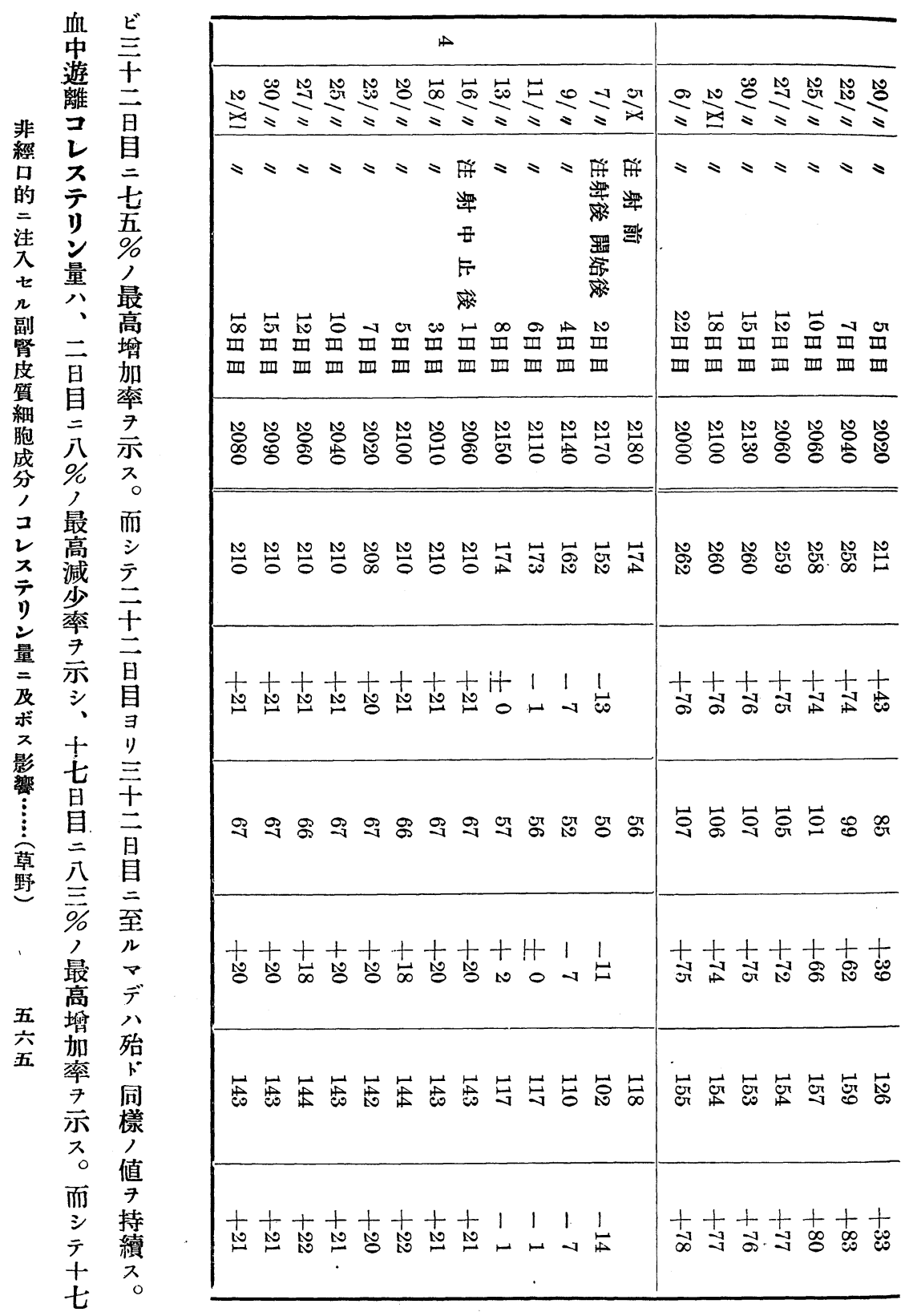




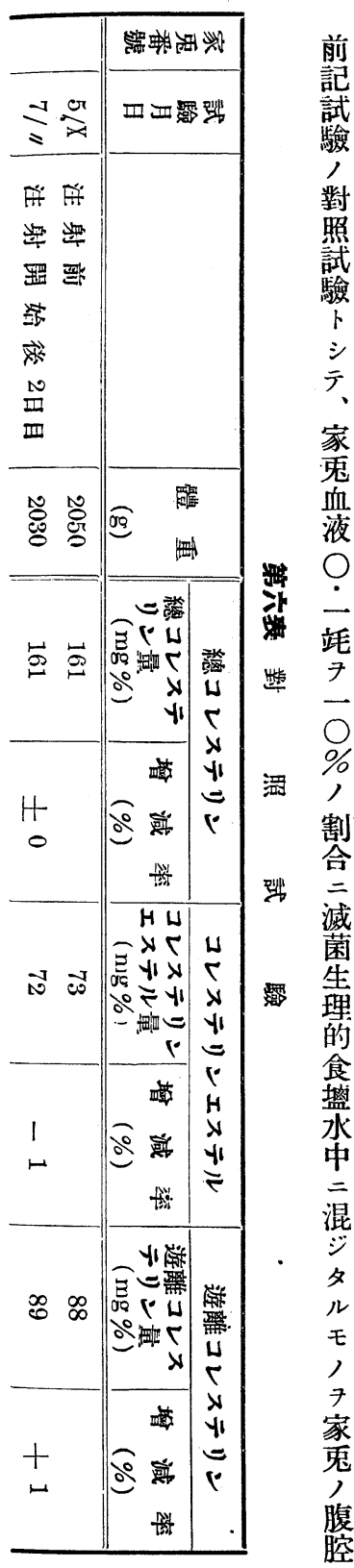

二 ス八目後續田日

遊 テ 却 2 及

コンデ $ン$ 日 血二 リ

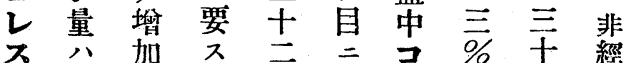

テ㞋ル日至レり 二

リ何 $\circ$ 目ル ス最日的

ンレ而、

量モ シ 副二デリ減二注

血テ孯二殆ソ 少至

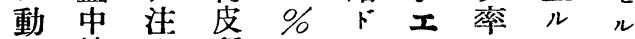

第摇總入筫人同ス

六大.岂中細最樣テ示デ腎

節ナレ止片高ノ几必皮

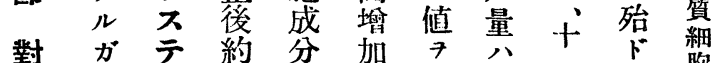

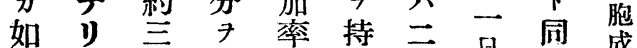

照 シ ン 週少 7 續 $\vec{日}$ 目樣分

○量間量示

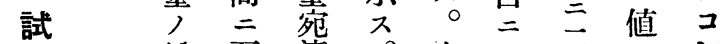

䁣 至連。血 - 二 7 レ

減 ル 續而中一布持

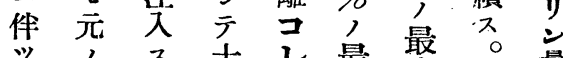

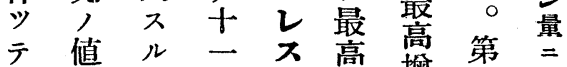

伯二ト日旦減增四及

娍復 $\neq$ 目》少萃例衣

シ 歸、寻量率 7 零影

其

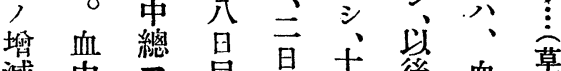

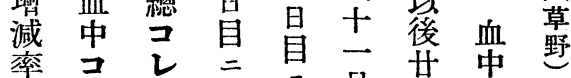

兩レス至二旦八總

者ステル四貝日元

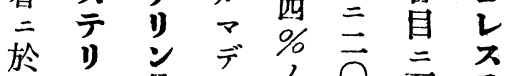

テン 量 八最 \% 至 テ五

略工公殆最 $\%$ ル 主六

々 ス 初占高最最的六

同テx同減最

量 少 值 示孫同注

テ、ビ ス

只遊 ル 持 シ 續十示值 始

僅 コ後 


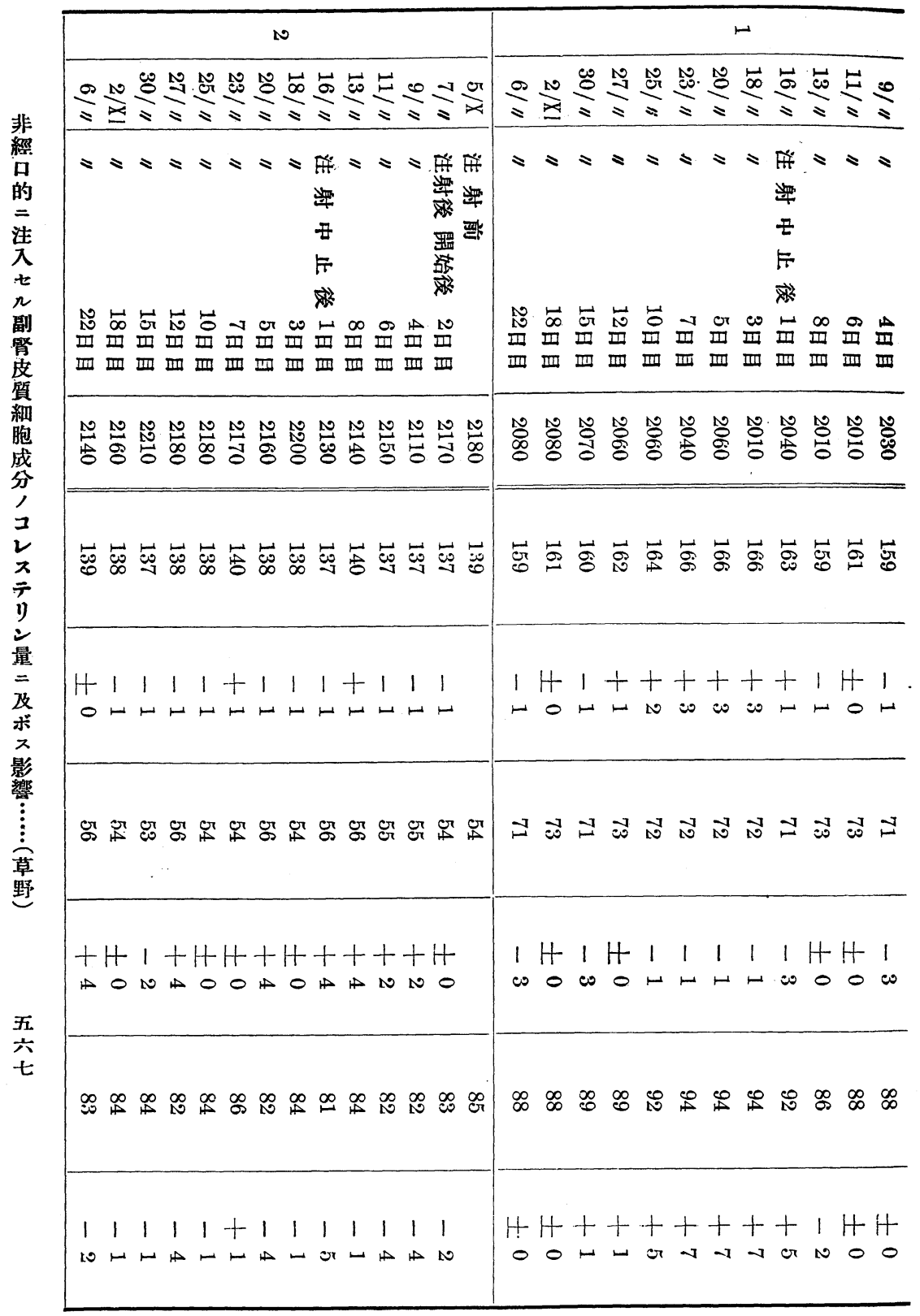




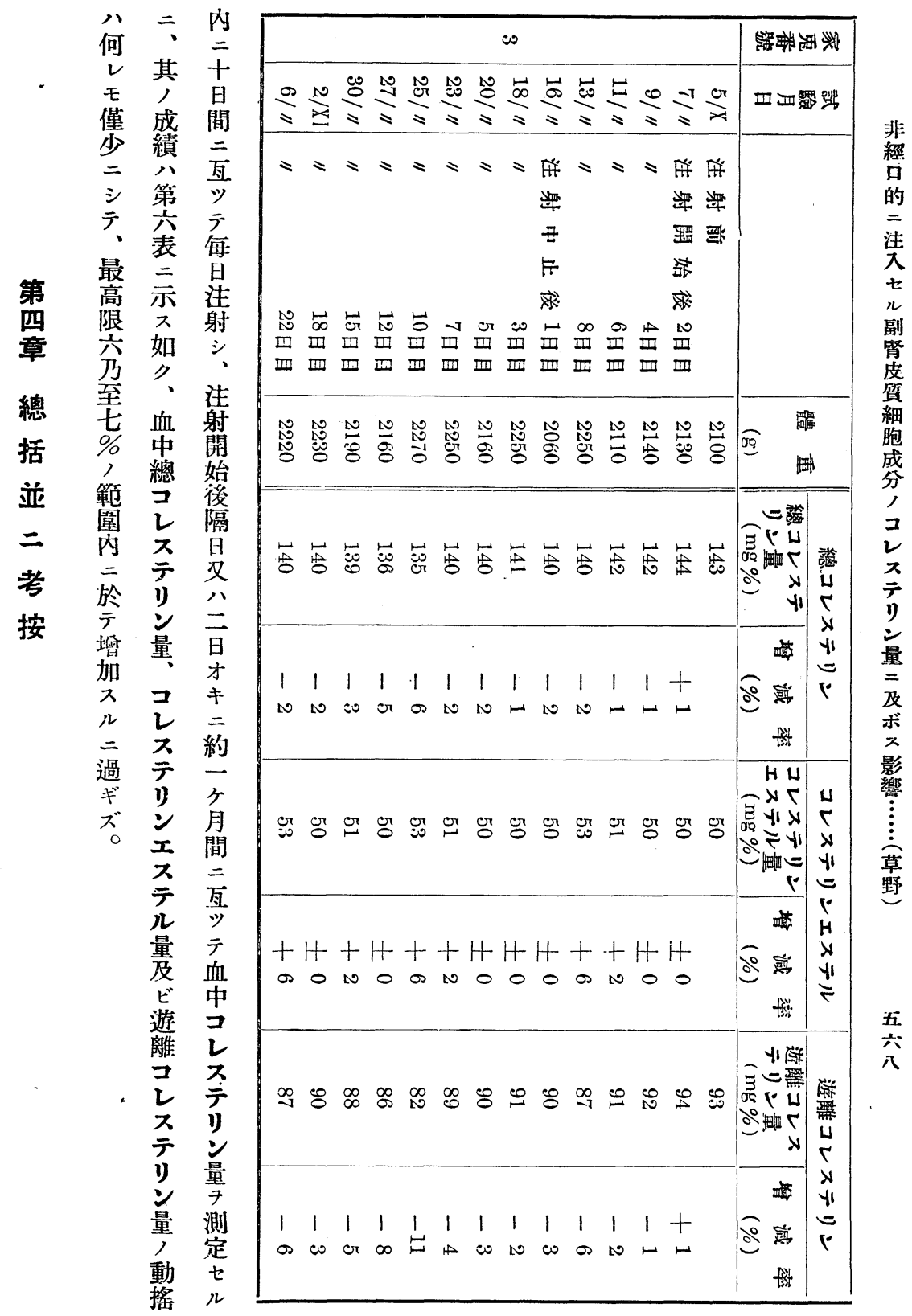




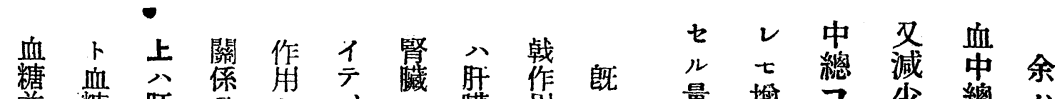

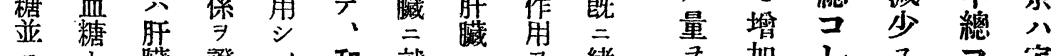

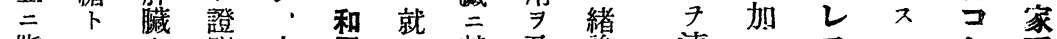
非脂，向明大界尔就及論連ス スル

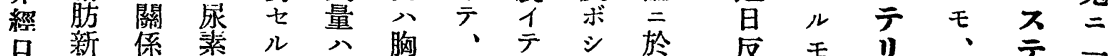
的陳 $\exists$ 成業機腺宮: 、宁覆其 $ン$ 其

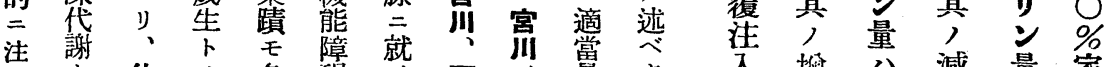
入

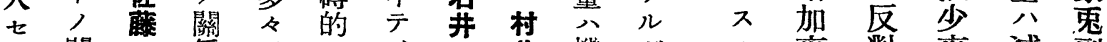

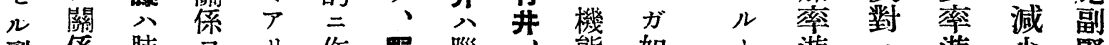
副係肺 $\exists$ ○作野腦、能如卜遊二遊少腎

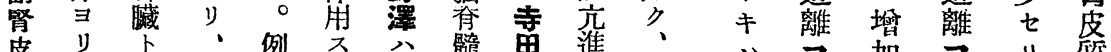

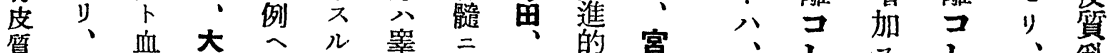

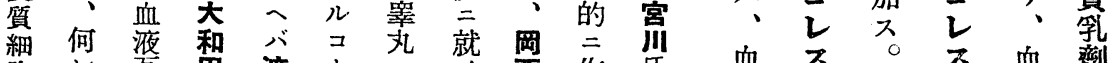

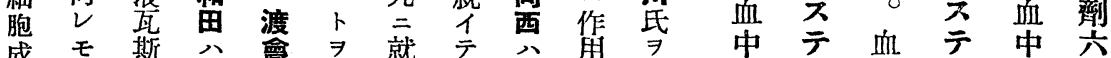

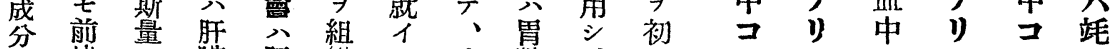

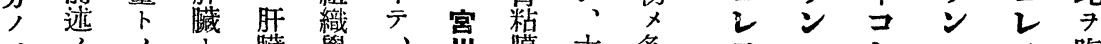

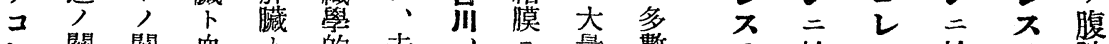

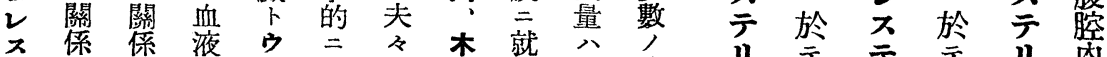
ス 係 係夜 ウ

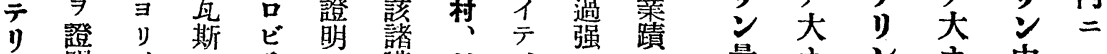
㝵、明、

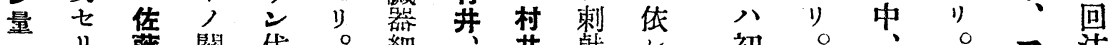
及

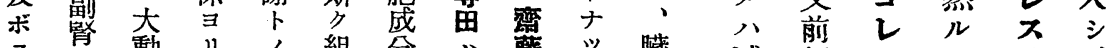

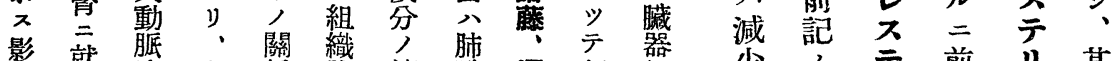
㩆就內 小係學適藏澤却細少ノ テ前り其

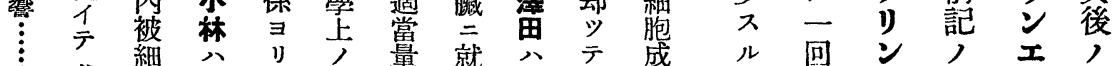
草 草中汿紫

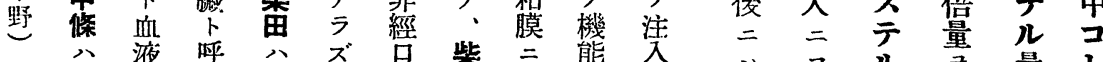

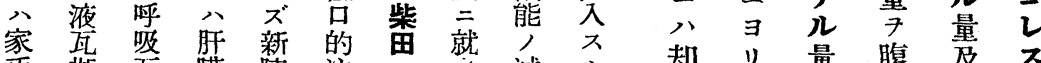

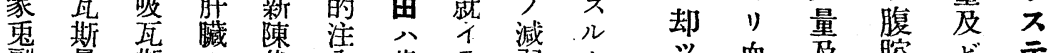

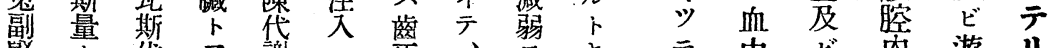
婜代厂謝八牙、 7 キ

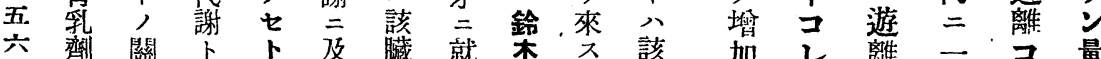

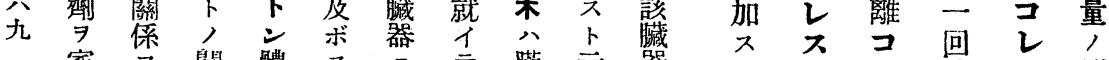

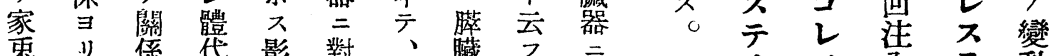
二、浪謝響 シ 石

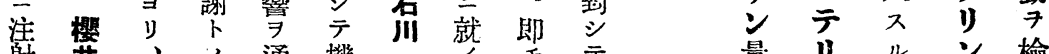

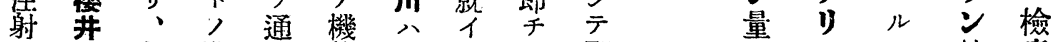

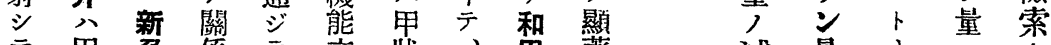
テ甲稳係京牀、㴶著減量中公七

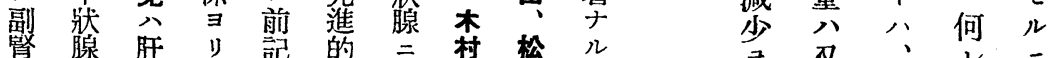

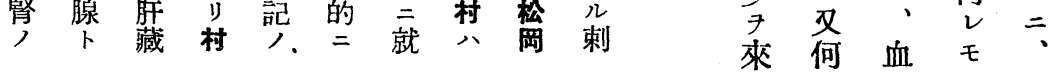




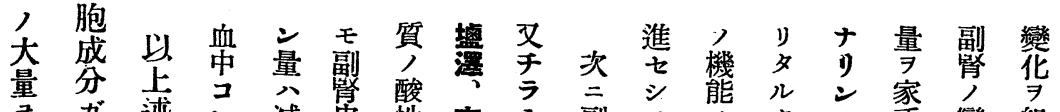

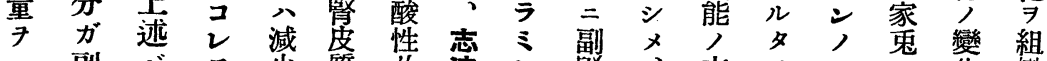

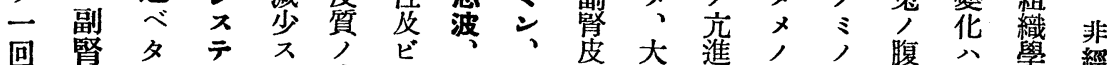

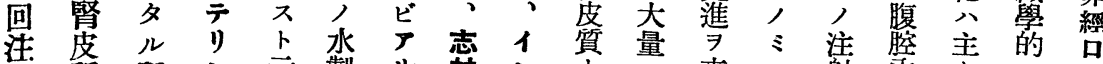

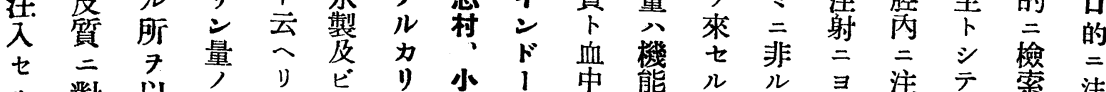

ル 對 上 增 。酒 性 田 ル

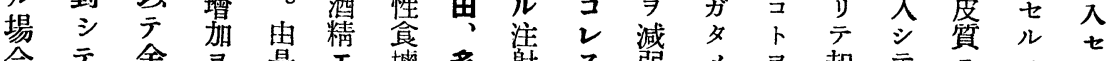

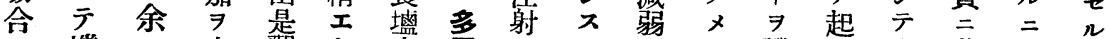

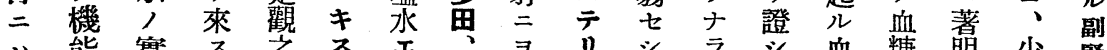

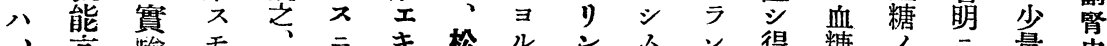

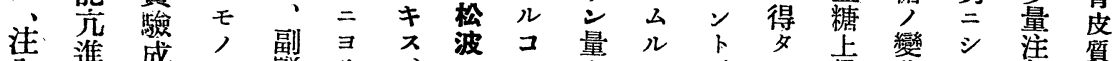

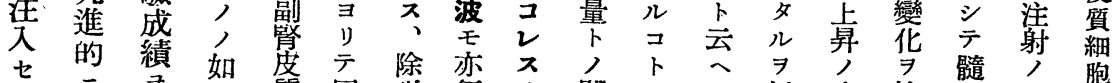

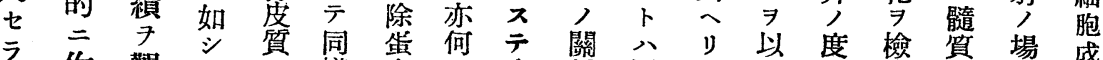

ラ 作 觀

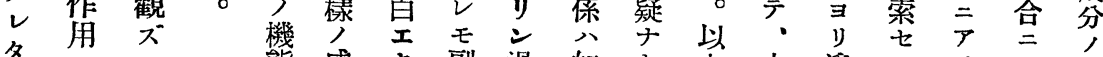

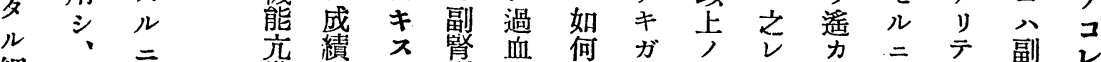

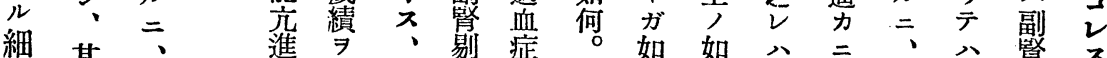

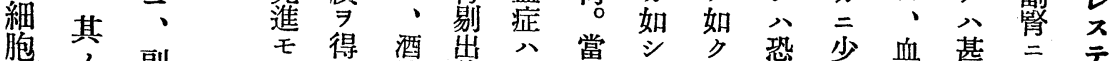

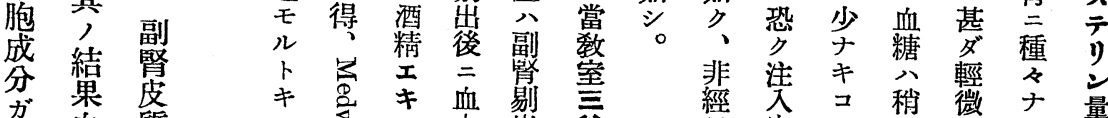

ガ副血質 =

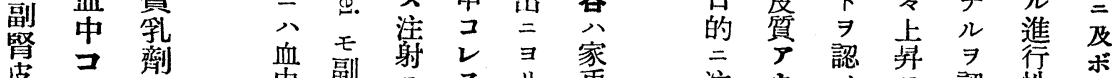

皮主,

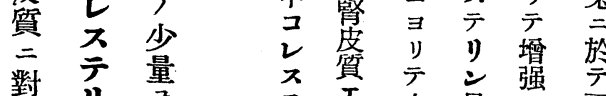

跍 7

機量回

能減注

障減入

碍少

的來場

作学

用モ心

其, ‘

其ナ 注

結、心

果》、ラ

血. v

中 該夕

コ缽儿

レ剩 細

テ 血量茧兩

リキ年 ラ 側

ンスコ增ル 副

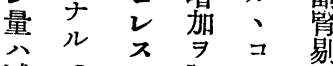

減 $\delta$ 認

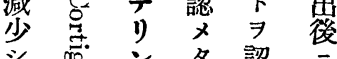

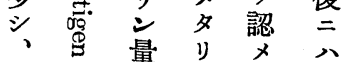

機注量少 メ合

能射滅 二吉 中

碍 三少方言方

セ必賞总

血占致饮

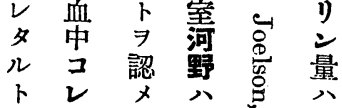

注门

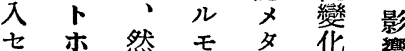

うル

モを之广。認

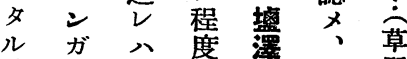

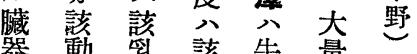

器動 乳該物量

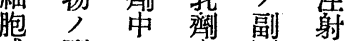

盛副含中孯公

分堅含含皮放

適皟ル

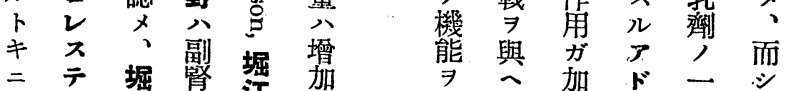

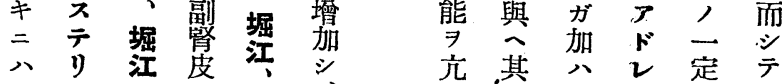

量適七、製行

當寻量 七變

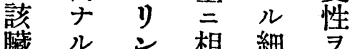

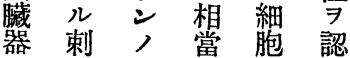

战作 $x$ 乳 


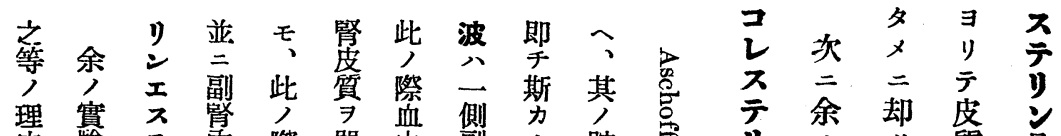

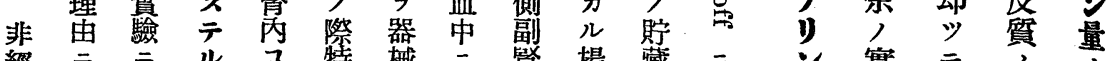
經 $=$ ル $コ$ 特 峨 $=$ 督場藏

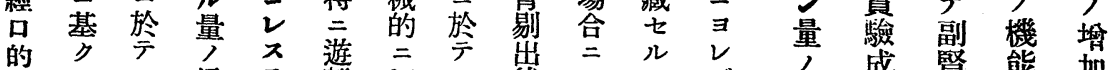

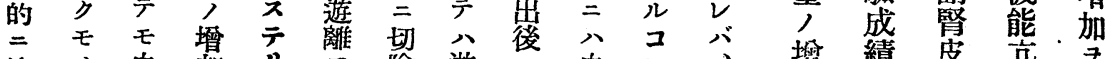

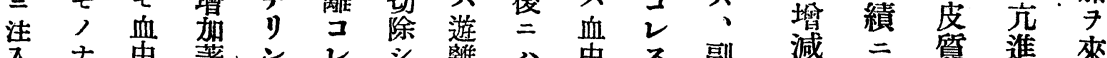
てナ虫著量 ス

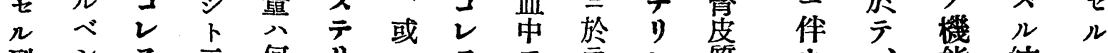

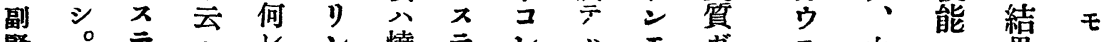
㹂。泉 皮壁

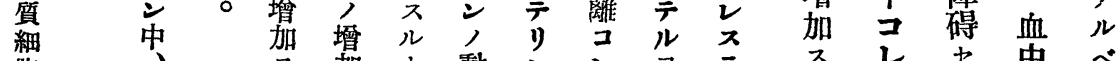

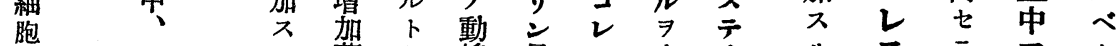

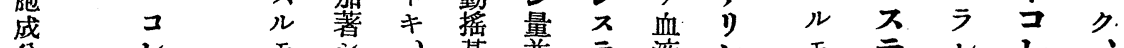

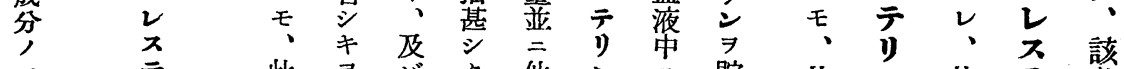

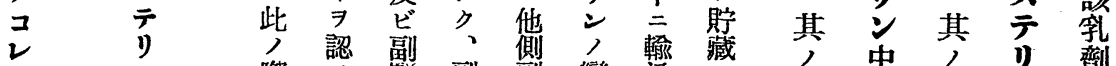
ス 際

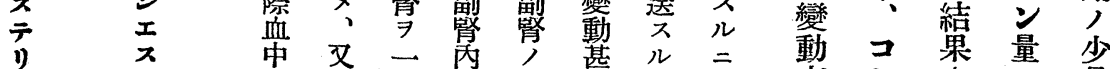

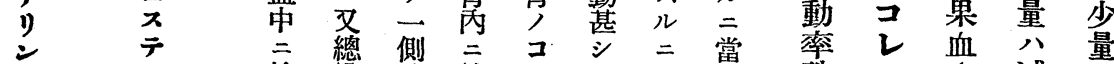
量 ル 於輸或於レク當鸴殊 ス中減

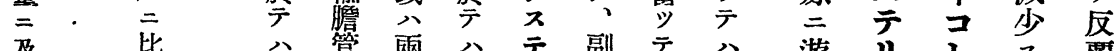

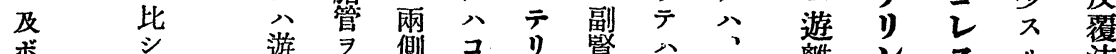

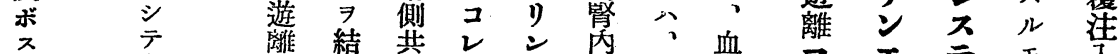
影 遊 紮 剔 $ᄌ$ 含

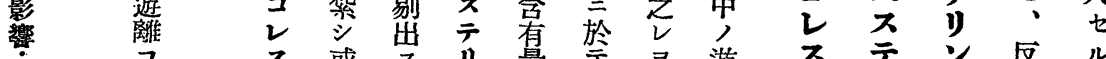
ス或スり 量テテ $テ$ 游 ス テ ソ $ル$

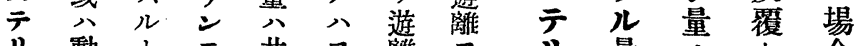

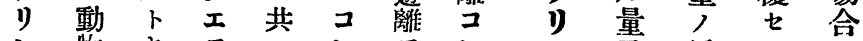

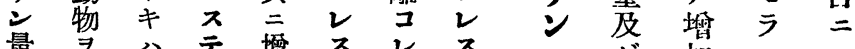

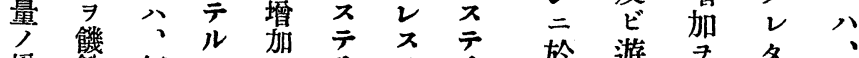

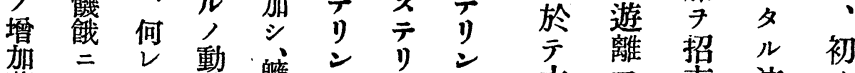

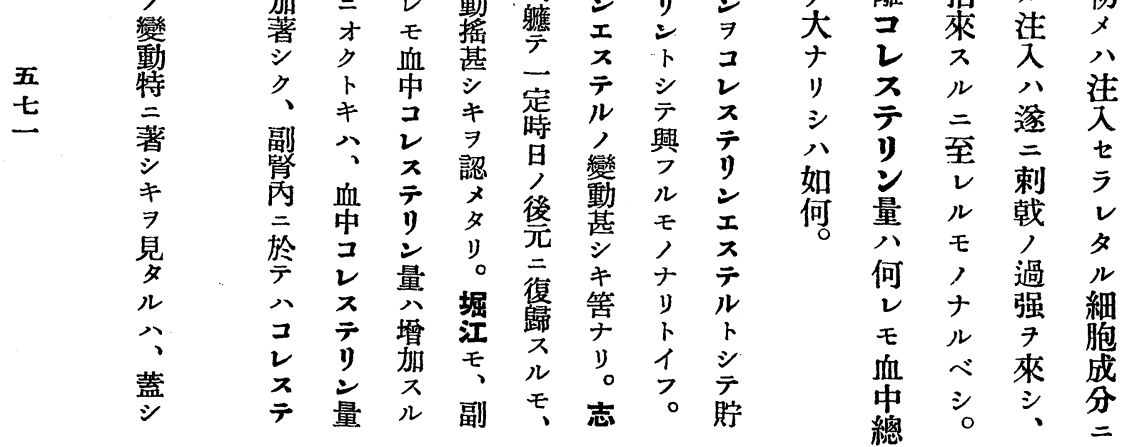




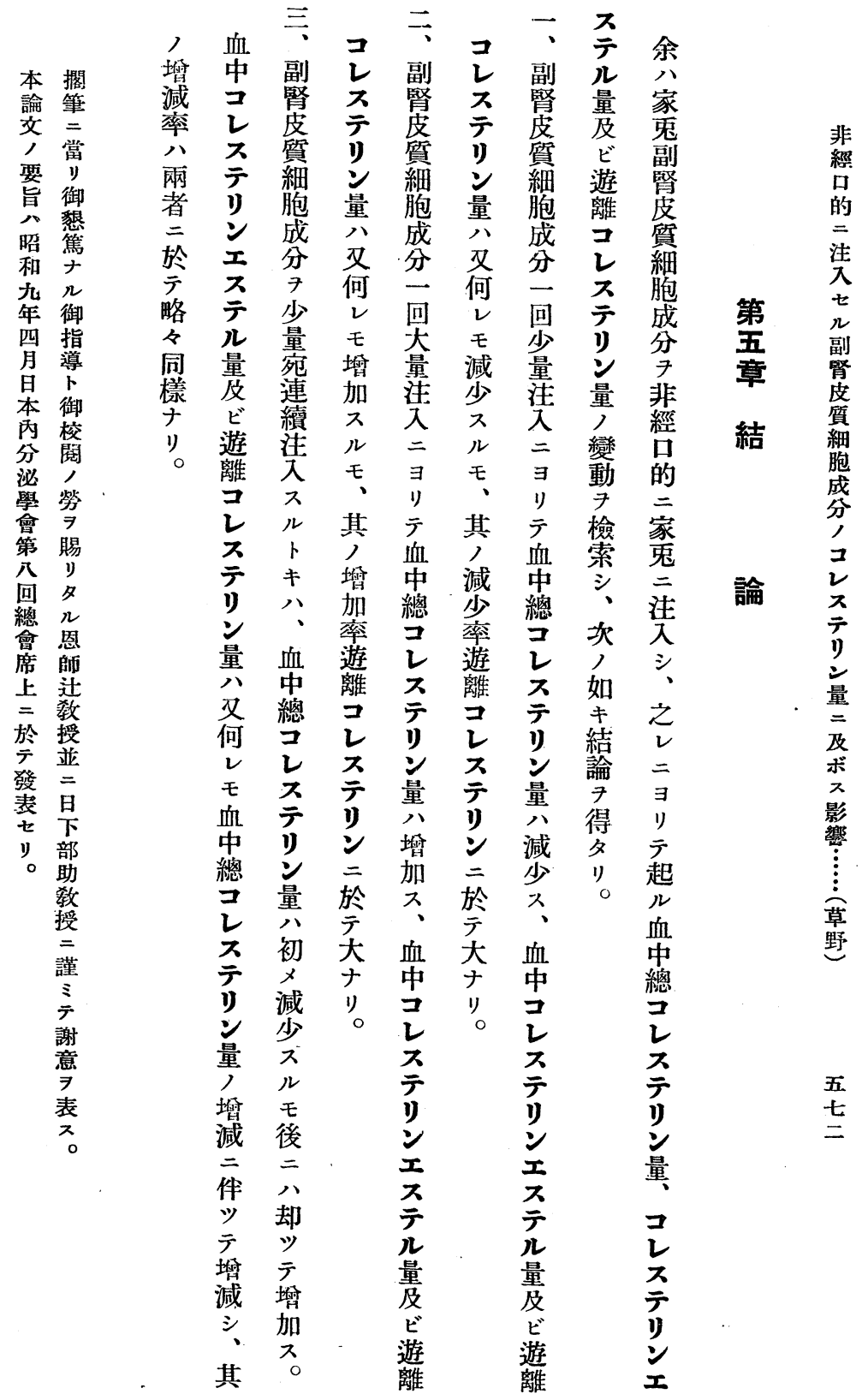




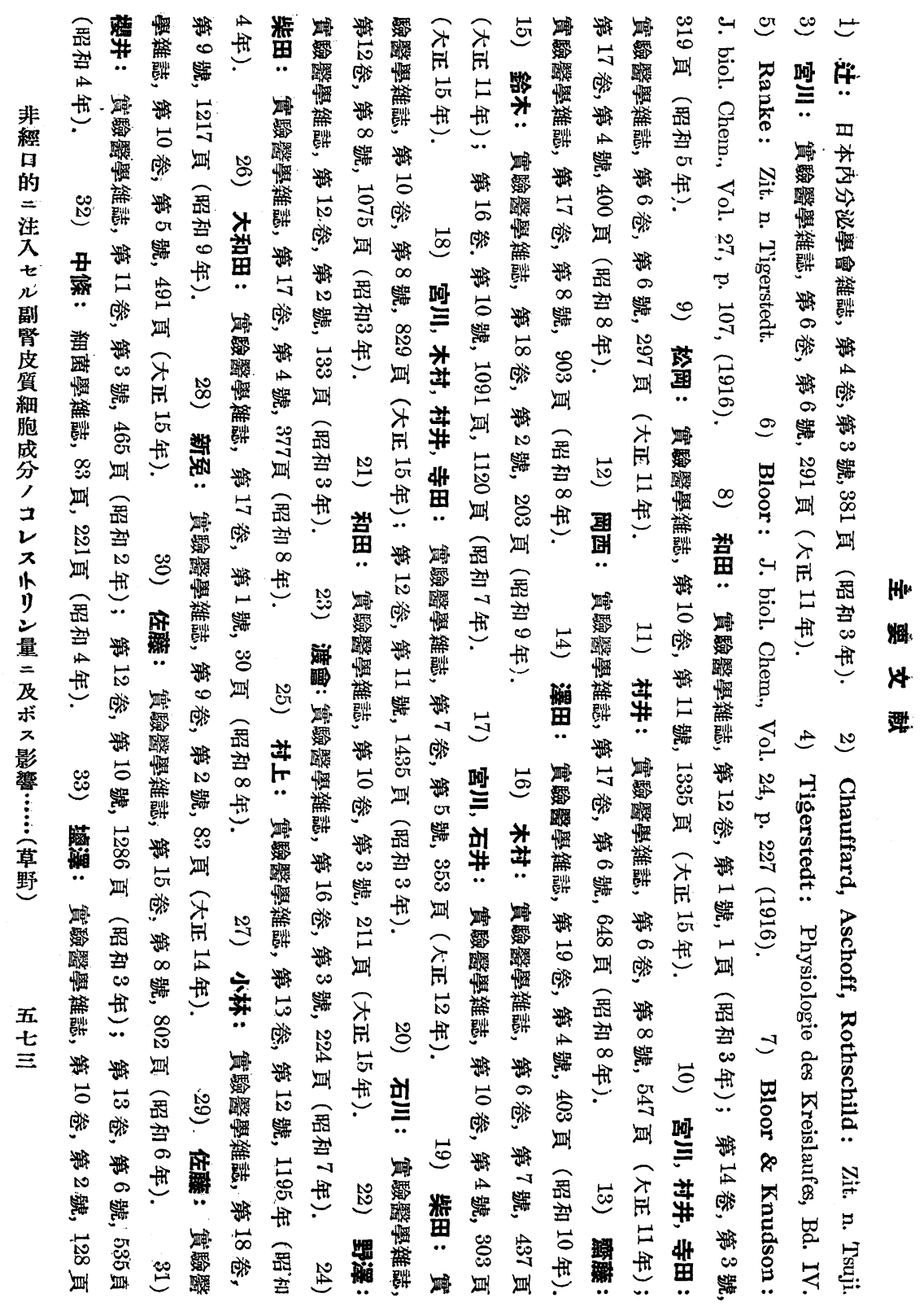




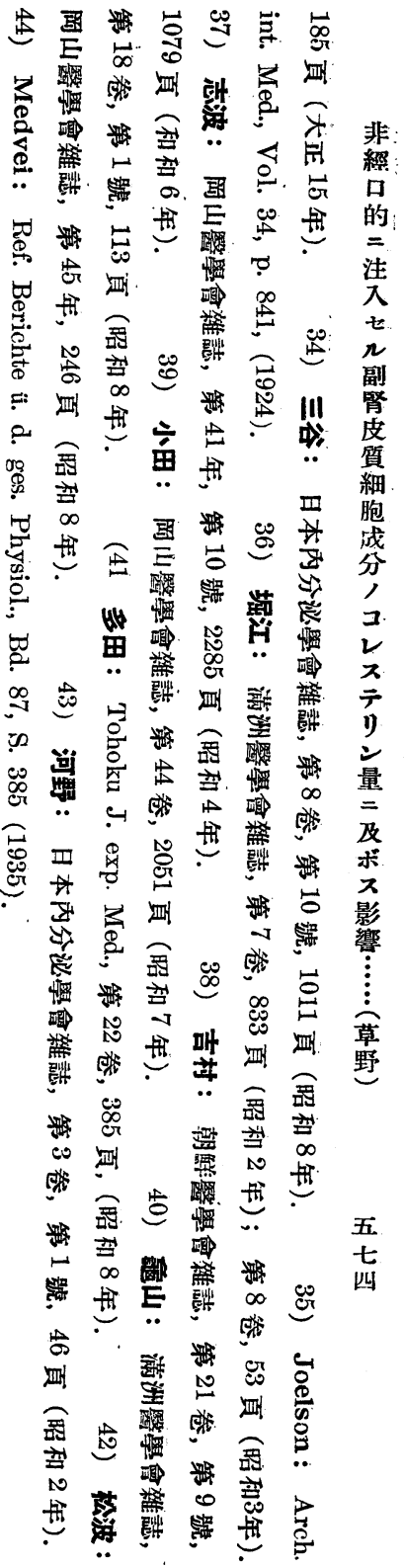




\title{
Über die Veränderungen des Cholesteringehalts im Blut bei nichtperoraler Einverleibung von Zellenbestandteilen der Nebennierenrinde.
}

\author{
Von \\ Dr. H. Kusano.
}

(Aus der I. Med. Klinik der Kaiserl. Univers, zu Kyoto in Japan. Direktor : Prof. Dr. K. Tsuji)

Der Verfasser untersuchte die Veränderungen des Gehaltes am gesamten Cholesterin, an Cholesterinester und an freiem Cholesterin im Blut des Kaninchens, wozu es durch intraperitoneale Injektion von Emulsion der Nebennierenrinde des Kaninchens kommt.

Die Resultate waren die folgenden:

1) Die einmalige Injektion einer kleineren Menge der Emulsion führte zu Verminderung des Gehalts am gesamten Cholesterin, an Cholesterinester und an freiem Cholesterin im Blut. Von den letzten zwei Stoffen nahm das freie Cholesterin besonders deutlich ab.

2) Durch die einmalige Injektion einer grösseren Emulsionsmenge kam es zur Zunahme des gesamten Cholesterins, Cholesterinesters und freien Cholesterins im Blut.

Von den letzten zwei Stoffen nahm das freie Cholesterin besonders deutlich zu.

3) Die wiederholte Injektion kleiner Emulsionsmengen führte erst zu Verminderung des gesamten Cholesterins, Cholesterinesters und freien Cholesterins im Blut, später jedoch zu Vermehrnng. (Autoreferat.) 